\title{
Pengaruh Model Pembelajaran Problem Based Learning dengan Integrasi Pendidikan Karakter terhadap Critical Thinking dalam PPKn Siswa Kelas IV
}

\author{
M. Dina Utami Dewi ${ }^{1}$, N. Dantes ${ }^{2}$, K. Yudiana ${ }^{3}$ \\ ${ }_{1,2,3}$ Universitas Pendidikan Ganesha \\ Singaraja, Indonesia \\ e-mail: dinautamadewi27@gmail.com ${ }^{1}$, dantes@undiksha.ac.id², \\ kadek.yudiana@undiksha.ac.id ${ }^{3}$
}

\begin{abstract}
Abstrak
Penelitian ini bertujuan untuk mengetahui Pengaruh Model Pembelajaran Problem Based Learning dengan Integrasi Pendidikan Karakter terhadap Critical Thinking dalam PPKn siswa kelas IV. Jenis penelitian ini adalah eksperimen semu (quasi eksperiment). Populasi penelitian ini adalah seluruh kelas IV di Gugus XV Kecamatan Buleleng yang berjumlah 226 Siswa. Penelitian ini menggunakan teknik random sampling: yang dirandom adalah kelas sebagai intac grup, sehingga didapatkan siswa kelas IV SD Negeri 1 Anturan sebagai kelas eksperimen dan siswa kelas IV SD Negeri 3 Kalibukbuk sebagai kelas Kontrol. Metode pengumpulan data yang digunakan adalah metode tes. Data yang dikumpulkan dianalisis menggunakan analisis statistik inferensial (Uji-t). Berdasarkan analisis data ditemukan bahwa terdapat pengaruh model pembelajaran problem based learning dengan intergrasi pendidikan karakter terhadap critical thinking PPKn siswa kelas IV di Gugus XV.
\end{abstract}

Kata kunci: Critical Thinking, Problem Based Learning, Pendidikan Karakter, PPKn

\begin{abstract}
This study aims to determine the effect of Problem Based Learning Learning Model with Character Education Integration on Critical Thinking in PPKn fourth grade students. This type of research is a quasi experiment (quasi experiment). The population of this study was all class IV in Buleleng District XV, which amounted to 226 students. This study uses a random sampling technique: the randomized class is the intacgrup, so it is obtained fourth grade students of $S D$ Negeri 1 Anturan as the experimental class and fourth grade students of SD Negeri 3 Kalibukbuk as the Control class. The data collection method used is the test method. Data collected was analyzed using inferential statistical analysis (t-test). Based on the data analysis, it was found that there was influence of the problem based learning learning model with the integration of character education towards critical thinking PPKn of fourth grade students in Group XV.
\end{abstract}

Keywords: Critical Thinking, Problem Based Learning, Character Education, PPKn. 


\section{Pendahuluan}

Pemerintah Republik Indonesia menyelenggarakan pendidikan yang diatur melalui beberapa peraturan yang berjenjang mulai dari peraturan yang tertinggi yaitu undang-undang dasar, undang-undang, peraturan pemerintah, dan peraturan menteri. Hal ini menunjukkan keseriusan pemerintah dalam melaksanakan pendidikan dalam segenap aspek kehidupan berbangsa dan bernegara. Telah ditetapkan delapan standar pendidikan yang dijadikan acuan dalam melaksanakan amanat undang-undang atau peraturan tersebut. Kualitas pendidikan dapat dilihat dari tingkat pencapaian standar yang ditetapkan. Peran dan kualitas pendidik mempunyai pengaruh yang signifikan pada pencapaian tujuan pendidikan dalam pembentukan sumberdaya manusia dalam aspek kognitif, afektif maupun keterampilan, baik dalam aspek fisik, sosial, mental, maupun spiritual. Hal ini jelas menuntut kualitas penyelenggaraan pendidikan yang baik serta pendidik yang professional agar kualitas hasil pendidikan dapat benar-benar optimal dalam kehidupan masyarakat. Untuk itu pendidik dituntut untuk selalu memperbaiki, mengembangkan diri dalam membangun dunia pendidikan.

Berdasarkan hasil observasi di gugus XV Kecamatan Buleleng diketahui permasalahan dalam pembelajaran di SD muncul walaupun para pendidiknya sudah kompeten dan professional hal ini disebabkan karena masalah pembelajaran tidak hanya dari sisi pendidik dan sarana yang ada tetapi juga akan muncul dari sisi siswa. Beberapa permasalahan yang ada dari sisi siswa misalnya, ramai sendiri atau mengajak teman ramai, tidak bisa diam di tempat, membuat keributan, melamun, tidur di kelas, keluar masuk kelas, kesulitan menangkap pelajaran, nilai rendah, menyontek, sering mengadu, dan merusak barang atau fasilitas sekolah. Kejadian tersebut sangat biasa ditemukan di sekolah dasar baik sekolah di kota maupun di desa.

Permasalahan sikap tidak dapat dipisahkan dari pengaruh lingkungan baik lingkungan fisik maupun lingkungan sosial. Siswa yang berasal dari keluarga yang harmonis dan dari ekonomi yang memadai cendrung menunjukkan sikap dan perilaku yang baik. Demikian juga sebaliknya, siswa yang kurang mendapat perhatian maupun dari keluarga yang kurang mampu cendrung mengalami banyak permasalahan dalam belajar. Oleh karena itu guru selaku pendidik harus dapat memberikan jalan keluar bagi siswa agar dapat mengurangi kesulitan belajar. Dalam kaitannya dengan kurikulum 2013, permasalahan sikap siswa dapat dilihat dalam kompetensi inti pertama dan kedua.

Pada kompetensi inti pertama berisikan sikap spiritual siswa diharapkan memiliki sikap religius dan dapat saling bertoleransi antar umat beragama. Sedangkan pada kompetensi kedua (KI II) siswa diharapkan memiliki sikap sosial yang baik seperti saling tolong menolong, menghargai, disiplin dan lain sebagainya. Kedua kompetensi ini menunjukkan karakteristik siswa karena pendidikan karakter sangat perlu bagi siswa untuk menjadi pribadi yang cerdas dan berkarakter. Berdasarkan Peraturan Presiden Nomor 87 Tahun 2017 menggalakkan tentang pendidikan karakter yang disebut dengan PPK. PPK adalah gerakan pendidikan di bawah tanggung jawab satuan pendidikan untuk memperkuat karakter peserta didik melalui harmonisasi olah hati, olah rasa, olah pikir, dan olah raga dengan pelibatan dan kerja sama antara satuan pendidikan, keluarga, dan masyarakat sebagai bagian dari Gerakan Nasional Revolusi Mental (GNRM). Penguatan pendidikan karakter sangat perlu dilakukan dalam pembelajaran agar pengetahuan dan keterampilan yang dimiliki siswa berimbang dengan karakternya. Pengetahuan yang dimiliki dapat disalah gunakan apabila siswa tidak memiliki karakter yang baik.

Berdasarkan Peraturan Presiden Nomor 87 Tahun 2017 ada lima karakter yang diharapkan dalam PPK yaitu religius, nasionalis, mandiri, gotong royong, dan integritas. Dalam kaitannya dengan kompetensi inti dalam muatan PPKn, KI-I yakni sikap religius dan $\mathrm{KI}-\mathrm{II}$ yaitu sikap sosial termasuk kedalam PPK sedangkan KI-III dan KI-IV termasuk ke dalam pengetahuan dan keterampilan. Oleh karena itu dalam pembelajaran PPKn, pendidikan karakter termasuk tujuan yang dituangkan dalam kompetensi inti pertama dan kedua.

Berdasarkan uraian tersebut, dapat ditegaskan bahwa $\mathrm{KI}-\mathrm{I}$ dan $\mathrm{KI}-\mathrm{Il}$ tidak dapat diajarkan secara teori atau dengan membaca buku tetapi harus dilakukan oleh peserta didik dalam segala kegiatannya. Misalnya dalam belajar kelompok siswa berinteraksi, kerjasama, saling menghargai, dan berinteraksi dengan temannya. Pada saat itulah dapat diketahui hasil belajar KI-I dan KI-II. Berbeda dengan KI-III dan KI-IV dapat diajarkan dan dapat diuji dengan soal-soal atau tes hasil belajar. Begitupula pada pembelajaran PPKn di sekolah dasar, $\mathrm{KI}$-I DAN $\mathrm{KI}-\mathrm{II}$ dilihat berdasarkan aktivitas siswa selama pembelajaran sedangkan KI-III dan KI-IV 
disesuaikan dengan instrument penilaian berdasarkan tujuan pembelajaran. Mata pelajaran PPKn di sekolah dasar masih memiliki banyak kendala.

Berdasarkan observasi awal yang dilakukan di gugus XV Kecamatan Buleleng khususnya yang berkaitan dengan sikap sosial siswa, para guru mengemukakan beberapa sikap siswa yang sering muncul dalam pembelajaran. Siswa sering berbuat ribut saat pembelajaran yang dapat mengganggu teman di sekitarnya. Siswa bermain mainan yang akan dimainkan waktu istirahat. Tidak dipungkiri siswa yang ribut juga mengajak teman sebelahnya untuk ribut pula dengan diawali mencari perhatian terhadap teman sebelahnya. Jika sudah ada kecocokan interaksi maka dipastikan menjadi sebuah perbincangan di luar pelajaran yang bisa mengganggu teman yang lainnya.

Sering pula siswa keluar masuk kelas meminta izin ke kamar mandi ketika proses pembelajaran berlangsung dengan berbagai alasan. Ada pula siswa yang selalu berkeliling dari bangku satu ke bangku yang lain. Hal ini terjadi karena siswa tersebut kurang nyaman di tempat duduknya atau kurang adanya rasa aman dari teman sebelahnya. Sering kali dijumpai siswa yang mengganngu temannya yang lain dengan berbagai cara, seperti melempar gulungan kertas, suka berbuat usil kepada temannya, sehingga temannya tidak konsentrasi lagi dalam belajar. Merusak barang atau fasilitas sekolah bagi siswa yang kurang mempunyai sifat tertib. Bermain bola di dalam kelas dan memecahkan kaca jendela, bermain yang menggunakan penggaris kayu dan akhirnya patah. Masih ada beberapa permasalahan yang sering muncul di sekolah dasar sebagai bagian dari fenomena anak-anak.

Masalah lain dalam pembelajaran, guru masih menggunakan metode ceramah, sehingga siswa kurang memahami materi yang diberikan oleh guru. Siswa belum bisa mengeluarkan pendapatnya yang berkaitan dengan permasalahan yang diberikan oleh guru. Siswa belum dapat memberikan suatu kesimpulan dari suatu permasalahan yang diberikan. Siswa belum dapat menentukan sumber-sumber yang tepat untuk memperoleh informasi, siswa juga belum dapat menggabungkan dan memperkirakan keputusan yang tepat terkait permasalahan yang diberikan. Hal tersebut berkaitan dengan berpikir kritis siswa yang masih rendah sehingga diperlukan suatu model pembelajaran inovatif yang dapat melatih kemampuan berpikir kritis siswa. Dalam hal ini model pembelajaran Problem Based Learning (PBL) atau pembelajaran berbasis masalah menjadi alternatif yang dapat diterapkan.

PBL merupakan salah satu model pembelajaran inovatif yang dapat memberikan kondisi belajar aktif kepada siswa (Ngalimun, 2017:172). Ditegaskan juga bahwa pembelajaran berbasis masalah dirancang berdasarkan masalah riil yang dapat meningkatkan kemampuan memecahkan masalah, dan keterampilan menerapkan konsep, sehingga dapat melatih kemampuan berpikir.

Ngalimun (2007:173) menyatakan bahwa PBL dapat juga dikatakan membangun kemampuan berpikir kritis atau critical thinking peserta didik terhadap fenomena yang disajikan dalam pembelajaran. Saat ini kemampuan critical thinking sangat penting dalam kehidupan sehari-hari, karena untuk mengembangkan kemampuan berpikir lainnya, seperti kemampuan untuk membuat keputusan dan menyelesaian masalah. Banyak fenomena dalam kehidupan sehari-hari yang perlu dikritisi. Menurut Fisher (2009:13) Pengertian critical thinking atau bisa disebut dengan berpikir kritis adalah aktivitas terampil yang bisa dilakukan dengan lebih baik atau sebaliknya dan pemikiran kritis yang baik dapat memenuhi beragam standar intelektual, seperti kejelasan, relevansi, kecukupan, koherensi, dan lain-lain. Dijelaskan juga bahwa kemampuan berpikir kritis siswa sangat perlu dikembangkan demi keberhasilannya dalam pendidikan dan dalam kehidupan bermasyarakat. Keterampilan berpikir kritis dapat dikembangkan atau diperkuat, melalui pembelajaran. Tidak semua pembelajaran secara otomatis akan mengembangkan keterampilan berpikir kritis. Pembelajaran yang mendorong diskusi dan berpendapat, mengekspresikan gagasan-gagasan, mendorong kerjasama, mengkaji, menemukan pengetahuan, mengembangkan tanggung jawab, yang akan mengembangkan berpikir kritis siswa.

Berdasarkan uraian tersebut, PBL yang diintegrasikan dengan penguatan pendidikan karakter akan terlihat dalam pembelajaran ketika siswa melaksanakan kerja kelompok. Karakter siswa ditunjukkan dengan menghargai pendapat temannya, bekerja sama, berinteraksi, dan tanya jawab dalam diskusi dalam kerja kelompok, mengamati, membandingkan, dan mengomunikasikan ide yang dimiliki. Melalui diskusi juga dapat melatih siswa dalam critical thinking atau berpikir kritis karena dalam PBL siswa dapat mengemukakan pendapat dan gagasan yang dimiliki. Banyak penelitian tentang PBL tetapi belum mengintegrasikan dengan PPK dan membangun kemampuan critical thinking. Beberapa hasil penelitian tentang PBL menemukan bahwa PBL lebih baik dari pada model pembelajaran konvensional yang biasa 
dilaksanakan di sekolah. Penelitian Wijaya (2015) melakukan penelitian yang berjudul "Pengaruh Model Pembelajaran Berbasis Masalah terhadap Hasil Belajar IPA Ditinjau dari Minat Siswa terhadap Pelajaran IPA pada Siswa SD di Gugus IV Kecamatan Manggis" hasil penelitianya menunjukkan terdapat perbedaan hasil belajar IPA antara kelompok siswa yang dibelajarkan dengan model pembelajaran berbasis masalah dengan kelompok siswa yang dibelajarkan dengan model pembelajaran konvensional dan terdapat perbedaan hasil belajar IPA antara kelompok siswa yang dibelajarkan dengan model pembelajaran berbasis masalah dan model pembelajaran konvensional pada kelompok siswa dengan minat terhadap pelajaran IPA tinggi.

Wulandari (2018) juga melakukan penelitian sejenis yang berjudul "Pengaruh Model Pembelajaran Problem Based Learning terhadap Hasil Belajar Matematika Siswa Kelas V SD Negeri Nanggulan" Hasil penelitiannya menunjukkan bahwa model pembelajaran problem based learning berpengaruh terhadap hasil belajar matematika siswa kelas V SD Negeri Nanggulan. Hal yang sama juga terdapat dalam hasil penelitian Abdurozzak et al (2016), dengan judul "Pengaruh Model Problem Based Learning terhadap Kemampuan Berpikir Kreatif Siswa", memperoleh hasil bahwa 1) terdapat peningkatan kemampuan berpikir kreatif siswa dengan menggunakan model PBL, 2) terdapat peningkatan hasil belajar siswa dengan menggunakan model PBL, 3) kemampuan berpikir kreatif siswa dengan menggunakan model PBL lebih baik daripada menggunakan model konvensional, 4) terdapat faktor pendukung dan penghambat dalam meningkatkan kemampuan berpikir kreatif siswa.

Berdasarkan beberapa hasil penelitian yang relevan tersebut, telah dibuktikan bahwa model pembelajaran PBL berpengaruh terhadap hasil belajar siswa dan terdapat pengaruh keterampilan berpikir kritis yang signifikan antara kelompok siswa yang belajar dengan menggunakan Problem Based Learning (PBL) dengan kelompok siswa yang belajar dengan menggunakan model pembelajaran konvensional. Dalam penelitian ini diungkapkan juga secara empiris pengaruh penerapan model pembelajaran Problem Based Learning yang diintegrasikan dengan pendidikan karakter dan pengaruhnya terhadap critical thinking dalam PPKn siswa kelas IV di Gugus XV Kecamatan Buleleng Kabupaten Buleleng tahun pelajaran 2018/2019.

\section{Metode}

Berdasarkan permasalahan yang telah dirumuskan, maka penelitian ini tergolong penelitian eksperimen semu (quasi eksperiment). Hal ini disebabkan tidak semua variabel (gejala yang muncul) serta kondisi eksperimen dapat diukur dan dikontrol secara ketat. Pemilihan desain ini disebabkan karena eksperimen dilakukan di beberapa kelas tertentu dengan siswa yang telah ada atau sebagaimana adanya. Bentuk rancangan eksperimen yang digunakan dalam penelitian ini adalah post-test only control group design. Selama penelitian, peneliti memanipulasi variabel bebas yang berupa model pembelaran Problem Based Learning (PBL) dengan intergrasi pendidikan karakter serta memberlakukannya pada kelompok eksperimen, sedangkan model pembelajaran konvensional yang diberlakukan pada kelompok kontrol. Pada akhir eksperimen, peneliti melakukan penilaian terhadap critical thinking PPKn siswa pada kelompok eksperimen dan kelompok kontrol untuk mengetahui ada tidaknya pengaruh efek manipulasi yang telah dilakukan.

Populasi artinya seluruh subjek di dalam wilayah penelitian dijadikan subjek penelitian (Sumanto, 2014). Sedangkan menurut Margono (2014) populasi adalah seluruh data yang menjadi perhatian kita dalam suatu lingkup dan waktu yang kita tentukan. Sejalan dengan hal tersebut Maolani (2015) menyebutkan bahwa popuasi adalah semua anggota dari suatu kelompok, orang, kejadian, atau objek-objek yang ditentukan dalam suatu penelitian. Populasi target penelitian ini adalah seluruh siswa kelas IV Sekolah Dasar Gugus XV yang terdiri dari dari SD N 1 Kalibukbuk, SD N 2 Kalibukbuk, SD N 3 Kalibukbuk, SD N 4 Kalibukbuk, SD N 1 Anturan, SD N 2 Anturan, SD N 3 Anturan, dan SD Triamerta. Penentuan sampel dalam penelitian ini dilakukan dengan teknik random sampling yang diacak adalah kelasnya untuk menentukan kelas eksperimen dan kelas kontrol. Hasil pengundian yaitu siswa kelas IV SD Negeri 1 Anturan sebagai kelas eksperimen yang berjumlah 37 siswa dan siswa kelas IV SD Negeri 2 Kalibukbuk sebagai kelas Kontrol yang berjumlah 28 siswa.

Metode pengumpulan data yang digunakan dalam penelitian ini adalah metode tes. Tes adalah cara (yang dapat dipergunakan) atau prosedur (yang perlu ditempuh) dalam rangka pengukuran dan penilaian di bidang pendidikan (Sudijono, 2015). Critical thinking PPKn siswa diukur dengan tes yang disusun dan dikembangkan berdasarkan materi, standar kompetensi, dan kompetensi dasar yang tertera dalam kurikulum SD. Tes yang dibuat adalah tes dalam 
bentuk esai. Susongko (2010) menyatakan bahwa, bentuk tes uraian, memberikan kebebasan kepada setiap penempuh tes untuk mengekspresikan daya nalarnya, sehingga jawaban yang diberikan oleh setiap penempuh tes akan menunjukkan kemampuan berpikir secara kompleks. Data yang dikumpulkan dianalisis menggunakan analisis statistik deskriptif kuantitatif Analisis kuantitatif adalah analisis yang menggunakan alat analisis bersifat kuantitatif, yaitu alat analisis yang menggunakan model-model, seperti model matematika (misalnya fungsi multivariat), model statistik, dan ekonometrik (Misbahuddin \& Iqbal Hasan 2014). dan statistic inferensial (uji-t).

\section{Hasil dan Pembahasan}

Deskripsi data hasil penelitian ini memaparkan rata-rata, median, modus, standar deviasi, varian, minimum, maksimum, dan rentang dari data hasil belajar PPKn siswa kelas IV SD N 1 Anturan dan siswa kelas IV SD N 2 Kalibukbuk tahun pelajaran 2018/2019 baik untuk kelas yang dibelajarkan dengan menerapkan model pembelajaran Problem Based Learning (PBL) dengan integrasi pendidikan karakter, maupun siswa yang dibelajarkan dengan menerapkan model pembelajaran konvensional. Perhitungan tersebut dikerjakan dengan bantuan program pengolahan angka Microsoft Office Excel 2007 dan SPSS 25. Hasil deskripsi data critical thinking kelompok eksperimen dan kelompok kontrol dapat dilihat pada tabel berikut ini.

Tabel 1. Ringkasan Analisis Critical Thinking dalam PPKn

\begin{tabular}{ccc}
\hline Hasil Analisis & Kelompok Eksperimen & Kelompok Kontrol \\
\hline N & 37 & 28 \\
Mean & 25,81 & 23,07 \\
Median & 25,80 & 23,17 \\
Modus & 25,70 & 20,50 \\
Standar Deviasi & 2,69 & 2,60 \\
Varian & 7,21 & 6,74 \\
Skor Maksimal & 30 & 28 \\
Skor Minimal & 21 & 19 \\
\hline
\end{tabular}

Berdasarkan tabel di atas, rata-rata skor critical thinking, untuk kelompok eksperimen melalui model pembelajaran Problem Based Learning (PBL) dengan integrasi pendidikan karakter adalah 25,81 dengan varian sebesar 7,21 dan standar deviasi 2,69. Skor maksimal yang diperoleh siswa adalah 30 , sedangkan skor minimal yang diperoleh adalah 21 . Sedangkan rata-rata skor critical thinking untuk kelompok kontrol melalui model pembelajaran konvensional adalah 23,07 dengan varian sebesar 6,74 dan standar deviasi 2,60. Skor maksimal yang diperoleh siswa adalah 28, sedangkan skor minimal yang diperoleh adalah 19. Berdasarkan data tersebut, skor critical thinking PPKn pada kelompok eksperimen melalui model pembelajaran Problem Based Learning (PBL) dengan integrasi pendidikan karakter, lebih tinggi dari kelompok kontrol dengan model pembelajaran konvensional. Untuk gambaran lebih lengkap dan jelas mengenai distribusi frekuensi skor ciritical thinking dalam PPKn siswa kelas IV SD N 1 Anturan yang mengikuti model pembelajaran Problem Based Learning (PBL) dengan intergrasi pendidikan karakter dapat dilihat pada histogram di bawah ini. 


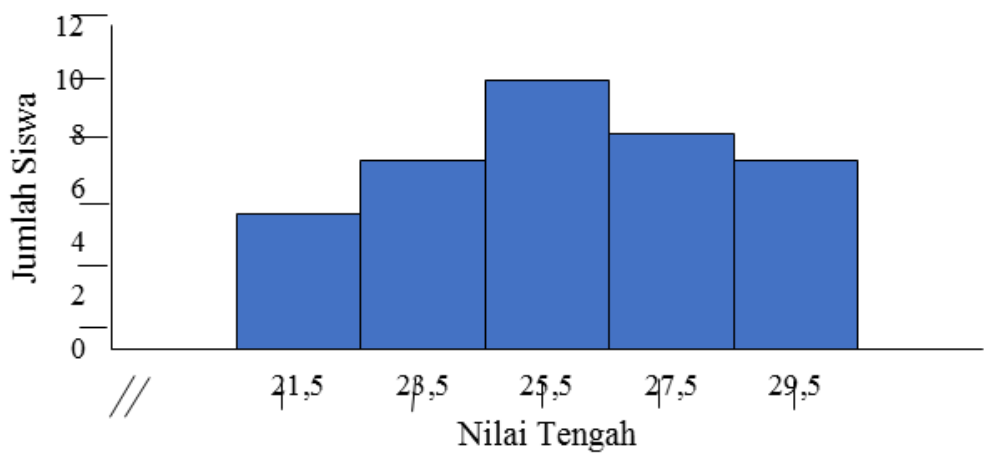

\section{Gambar 1. Histogram Critical Thinking PPKn Siswa Kelompok Eksperimen}

Selanjutnya dikonversikan ke tabel skala penilaian di dapatkan skor rata-rata critical thinking siswa kelompok eksperimen adalah 25,81. Berdasarkan hasil konversi, dapat dinyatakan bahwa rata-rata skor critical thinking dalam PPKn siswa pada kelompok eksperimen termasuk dalam kategori sangat baik. Untuk gambaran lebih lengkap dan jelas mengenai distribusi frekuensi skor critical thinking dalam PPKn siswa kelas IV SD N 3 Kalibukbuk yang mengikuti model pembelajaran konvensional dapat dilihat pada histogram berikut ini.

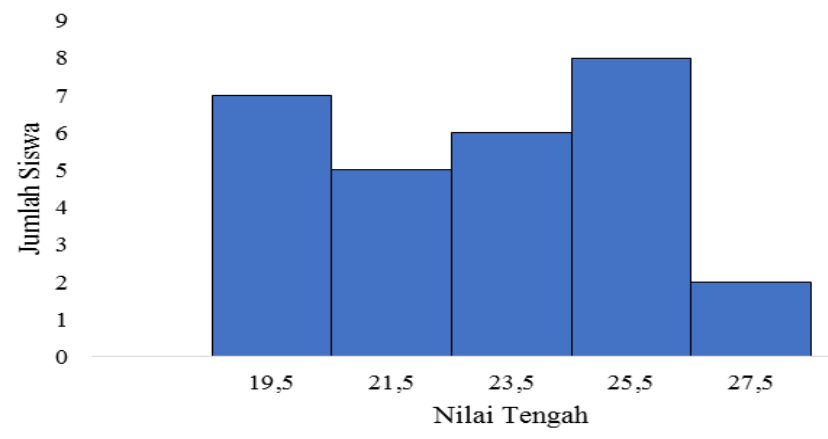

\section{Gambar 2. Histogram Critical Thinking dalam PPKn Kelompok Kontrol}

Berdasarkan Mean Ideal dan Standar Deviasi Ideal, maka dapat ditentukan rentangan skor dari masing-masing kategori berdasarkan tabel 4.3 Skor rata-rata critical thinking PPKn siswa kelompok kontrol adalah 23,07. Berdasarkan hasil konversi, dapat dinyatakan bahwa rata-rata hasil belajar siswa pada ranah kognitif kelompok kontrol termasuk dalam kategori baik.

Selanjutkan dilakukannya uji prasyarat yaitu uji normalitas dilakukan untuk menguji apakah suatu distribusi empirik mengikuti ciri-ciri normal. Uji normalitas data dilakukan terhadap data post-test hasil belajar PPKn kelas eksperimen dan kontrol. Perhitungan dibantu dengan menggunakan SPSS 25. Adapun kriteria pengujian jika signifikansi $>0,05$, maka $\mathrm{H} 0$ diterima dan data berdistribusi normal, sedangkan jika signifikansi $<0,05$, maka $\mathrm{HO}$ ditolak dan data tidak berdistribusi normal. Berdasarkan analisis yang dilakukan, pada Tabel 2 disajikan hasil uji coba sebaran data dengan bantuan SPSS.

Tabel 2. Rekapan Uji Normalitas Data Critical Thinking PPKn

\begin{tabular}{clcccc}
\hline No & $\begin{array}{c}\text { Kelompok Data } \\
\text { Critical Thinking }\end{array}$ & Statistik & df & Sig. & Status \\
\hline 1 & Eksperimen & 0,111 & 37 & 0,200 & Normal \\
2 & Kontrol & 0,158 & 28 & 0,072 & Normal \\
\hline
\end{tabular}

Dari hasil perhitungan mengguakan rumus kolmogorov smirnov dengan bantuan SPSS 25 , tes critical thinking dalam PPKn siswa kelompok eksperimen 0,200 $>0,05$. yang berarti data hasil post-test siswa kelompok eksperimen berdistribusi normal. Sedangkan data hasil post-test 
kelas kontrol 0,072 >0,05, yang berarti data hasil post-test kelompok kontrol berdistribusi normal.

Setelah data berdistribusi normal di lanjutkan dengan uji homogenitas dilakukan pada kelompok eksperimen dan kontrol dengan menggunakan bantuan SPSS 25 dengan kriteria data jika sig. $>0,05$, maka $\mathrm{HO}$ diterima dan varians homogen, sedangkan jika sig. $<0,05$, maka HO ditolak dan varians tidak homogen. Rangkuman hasil uji homogenitas adalah sebagai berikut.

Tabel 3. Ringkasan Hasil Uji Homogenitas Kelompok Eksperimen dan Kelompok Kontrol

\begin{tabular}{|c|c|c|c|c|c|}
\hline \multicolumn{6}{|c|}{ Uji homogenitas varian } \\
\hline & & $\begin{array}{l}\text { Levene } \\
\text { Statistik }\end{array}$ & $\mathrm{df1}$ & df2 & Sig. \\
\hline \multirow[t]{4}{*}{$\begin{array}{l}\text { Critical } \\
\text { Thinking }\end{array}$} & $\begin{array}{l}\text { Berdasarkan rata-rata } \\
\text { (mean) }\end{array}$ & 0,320 & 1 & 63 & 0,573 \\
\hline & Berdasarkan median & 0,257 & 1 & 63 & 0,614 \\
\hline & $\begin{array}{l}\text { Disesuaikan berdasarkan } \\
\text { median dengan df }\end{array}$ & 0,257 & 1 & 60,206 & 0,614 \\
\hline & $\begin{array}{l}\text { Berdasarkan rata-rata yang } \\
\text { dipangkas }\end{array}$ & 0,300 & 1 & 63 & 0,586 \\
\hline
\end{tabular}

Berdasarkan tabel di atas, dapat dilihat bahwa sig. pada Based in Mean 0, $573>0,05$, sehingga $\mathrm{HO}$ diterima dan varians homogen. Hal ini menunjukkan bahwa data kelompok eksperimen dan kelompok kontrol memiliki varians yang homogen.

Pegujian hipotesis, yakni dari perhitungan hasil Uji t dengan bantuan SPSS, diperoleh hasil nilai sig. (2-tailed) $0,000<0,05$. Dengan demikian $\mathrm{H} 0$ ditolak dan $\mathrm{H} 1$ diterima, yang artinya terdapat pengaruh model pembelajaran problem based learning dengan integrasi pendidikan karakter terhadap critical thinking dalam PPKn siswa kelas IV di Gugus XV Kecamatan Buleleng Kabupaten Buleleng tahun pelajaran 2018/2019.

Tabel 4. Ringkasan Hasil Uji-t

\begin{tabular}{lllll}
\hline \multirow{2}{*}{ Critical Thinking } & T & Df & Sig.(2-tailed) \\
& $\begin{array}{l}\text { Equal } \\
\text { Variances }\end{array}$ & 4,422 & 63 & 0,000 \\
& $\begin{array}{l}\text { Equal variences } \\
\text { not Assumed }\end{array}$ & 4.498 & 61,388 & 0,000 \\
\hline
\end{tabular}

Berdasarkan deskripsi data hasil penelitian, diketahui bahwa kelompok siswa yang mengikuti pembelajaran dengan model pembelajaran problem based learning dengan integrasi pendidikan karakter mendapatkan critical thinking dalam PPKn yang lebih tinggi dibandingkan dengan kelompok siswa yang mengikuti pembelajaran dengan model pembelajaran konvensional. Hal ini dilihat dari rata-rata skor critical thinking dalam PPKn siswa. Kelompok eksperimen yang mengikuti pembelajaran dengan menggunakan model pembelajaran problem based learning dengan integrasi pendidikan karakter memiliki skor rata-rata skor critical thinking dalam PPKn sebesar 25,81 yang berada pada kategori sangat baik. Sedangkan kelompok kontrol yang mengikuti pembelajaran dengan model pembelajaran konvensional memiliki ratarata skor critical thinking dalam PPKn sebesar 23,07 yang berada pada kategori baik. Hal ini menunjukkan kualitas critical thinking dalam PPKn siswa yang diberikan perlakuan model pembelajaran problem based learning dengan integrasi pendidikan karakter memiliki skor yang lebih tinggi. 
Berdasarkan pengujian hipotesis menggunakan uji-t dengan bantuan SPSS 25, diketahui sig. (2-tailed) $0,000<0,05$. Dengan demikian $\mathrm{HO}$ ditolak, yang artinya terdapat pengaruh model pembelajaran problem based learning dengan intergrasi pendidikan karakter terhadap critical thinking dalam PPKn siswa kelas IV di Gugus XV Kecamatan Buleleng Kabupaten Buleleng tahun pelajaran 2018/2019. Adanya pengaruh model pembelajaran problem based learning dengan intergrasi pendidikan karakter terhadap critical thinking dalam PPKn dikarenakan PBL melibatkan peserta didik untuk memecahkan suatu masalah melalui tahap metode ilmiah sehingga peserta didik dapat mempelajari pengetahuan yang berhubungan dengan masalah tersebut serta memiliki keterampilan untuk memecahkan masalah. Hal ini didukung oleh karakteristik model pembelajaran problem based learning menurut Rusman (2012) yaitu (1) belajar dimulai dari suatu masalah, (2) memastikan bahwa permasalahn yang diberikan berhubungan dengan dunia nyata pembelajar,

mengorganisasikan pembelajaran diseputar permasalahan, bukan diseputar disiplin ilmu.

Pada pembelajaran ini, siswa diberikan kesempatan untuk lebih aktif dalam kegiatan di kelas. Keaktifan siswa terlihat dari kegiatan diskusi kelas, membangun sendiri pengetahuannya. Permasalahan yang diberikan dalam pembelajarannya merupakan permasalahan yang relevan dengan apa yang siswa hadapi dalam kehidupan sehari-hari. Masalah yang diberikan berfungsi sebagai stimulus (motivator) untuk mengaktifkan siswa dalam belajar. Selain itu, dengan adanya integrasi dengan pendidikan karakter, maka karakter siswa dibina, disamping memberikan pengetauan kognitif. Berdasarkan peraturan presiden nomor 87 tahun 2017 adapun karakter yang ditanamkan dalam pembelajaran ini adalah religius, integritas, kemandirian, rasa ingin tahu, gotong royong, tanggung jawab, nasionalis, dan komunikatif. Karakter tersebut ditanamkan dalam tiap-tiap langkah pembelajaran Problem based learning.

Menuurt Arends (2008) model pembelajaran Problem based learning terdiri dari 5 fase. Sebelum fase pertama dimulai, siswa dan guru berdoa bersama untuk membuka pembelajaran (menanamkan karakter religius). Selanjutnya dimulai dengan fase pertama yaitu memberikan orientasi mengenai masalah pada peserta didik (mengembangkan karakter integritas). Pada fase ini guru membahas tujuan pembelajaran, mendeskripsikan kebutuhan penting, dan memotivasi peserta didik untuk terlibat pada kegiatan pembelajaran. Berdasarkan RPP pada pertemuan pertama, pada fase ini guru juga memberikan apersepsi berupa masalah kepada peserta didik dengan menanyakan perbedaan kondisi masyarakat yang tinggal di daerah pegunungan dengan daerah pesisir pantai. Jika dikaitkan dengan aspek critical thinking, fase ini termasuk dalam aspek elementary clarification (memberikan penjelasan dasar). Pada aspek ini siswa mengidentifikasi jawaban yang mungkin dengan mencari perbedaan kondisi masyarakat yang tinggal di daerah pegunungan dengan daerah pesisir pantai. Siswa memberikan penjelasan dasar dan memberikan contoh untuk memperjelas jawaban.

Fase kedua guru mengorganisasikan pesertadidik untuk meneliti (mengembangkan karakter kemandirian dan rasa ingin tahu). Pada fase ini siswa mencari faktor penyebab keragaman masyarakat melalui membaca pada buku siswa. Kemudian siswa mencari informasi mengenai perbedaan kehidupan masyarakat di pegunungan, pesisir pantai, dan perkotaan. Fase ini berkaitan dengan aspek kedua critical thinking yaitu the basic for the decision (menentukan dasar pengambilan keputusan). Siswa menilai sumber mana yang tepat agar menemukan informasi yang dibutuhkan. Selain itu siswa menentukan dan memilah informasi yang sesuai. Fase ketiga yaitu membantu investigasi mandiri dan kelompok (menanamkan karakter kemandirian dan gotong royong). Pada fase ini siswa secara berkelompok berdiskusi mengenai perbedaan kehidupan suku-suku yang ada di Indonesia berkaitan dengan kondisi wilayahnya. Siswa secara berkelompok mengisi Lembar Kerja Siswa (LKS) yang diberikan guru untuk membandingkan kehidupan suku-suku yang ada di Indonesia berdasarkan kondisi wilayahnya. Fase ini adalah lanjutan dari aspek kedua. Ketika siswa telah memutuskan sumber yang tepat dan informasi yang tepat untuk menjawab permasalahan yang diberikan guru, siswa menarik kesimpulan (inference), sesuai dengan aspek ketiga ciritcal thinking. Pada aspek ini siswa mendeduksi dan mempertimbangkan hasil deduksi suatu informasi yang diperoleh, menginduksi dan mempertimbangkan hasil induksi, serta membuat dan mempertimbangkan jawaban dari masalah yang diberikan.

Fase keempat yaitu mengembangkan dan mempresentasikan artefak dan exhibit (menanamkan karakter tanggung jawab dan nasionalis). Pada aspek ini perwakilan kelompok mempresentasikan hasil diskusi kelompoknya, sedangkan kelompok lain menanggapi presentasi dari kelompok penyaji. Fase ini berkaitan dengan aspek critical thinking yaitu advanced clarification (memberikan penjelasan lanjut). Kelompok lain mengidentifikasi pekerjaan kelompok penyaji. Antar siswa saling mengajukan pendapat dan memberikan 
penjelasan lanjut mengenai pendapat yang dikemukakan. Fase kelima adalah analisis dan evaluasi proses mengatasi masalah (menanamkan karakter komunikatif). Pada fase ini, siswa bersama guru menyamakan persepsi, apabila ada informasi yang keliru guru meluruskannya. Fase ini berkaitan dengan aspek critical thinking yaitu supposition and integration (memperkirakan dan menggabungkan). Pada aspek ini siswa mempertimbangkan alasan atau asumsi-asumsi yang diragukan. Dalam artian apabila ada pendapat yang kurang tepat dikemukakan kelompok penyaji, kelompok lain berusaha memberikan asumsi. Namun apabila asumsi tersebut belum menemukan titik terang, maka guru meluruskan asumsi tersebut sehingga tercipta pengetahuan yang utuh. Untuk menutup pembelajaran, siswa dan guru kembali berdoa bersama (menanamkan karakter religius).

Tahapan pembelajaran menggunakan model pembelajaran problem based learning dengan integrasi pendidikan karakter, berbeda halnya dengan pembelajaran dengan model pembelajaran konvensional. Dalam penelitian ini, guru berperan sebagai pemberi informasi kepada siswa, sedangkan siswa berperan memperoleh informasi dengan tepat melalui kegiatan mendengarkan dan membaca informasi. Penjelasan yang diberikan oleh guru masih berorientasi pada buku dan tidak menggunakan model pembelajaran ataupun mengintegrasikan dengan pendidikan karakter. Hal ini menyebabkan siswa cenderung menghafalkan setiap konsep yang diberikan dan kurang dapat memahami serta menghubungkan antara materi-materi yang berhubungan. Pada pembelajaran konvensional, penekanannya sering hanya pada penyelesaian tugas, sehingga siswa tidak terbiasa untuk berpikir kritis (critical thinking). Hal ini akan menyebabkan skor berpikir kritis (critical thinking) siswa menjadi lebih rendah dibandingkan penggunaan model pembelajaran problem based learning dengan intergrasi pendidikan karakter.

Keberhasilan penerapan model pembelajaran problem based learning dengan intergrasi pendidikan karakter, didukung oleh penelitian yang dilakukan oleh Saputra (2015), Hasil penelitiannya menunjukkan bahwa model pembelajaran berbasis masalah dapat meningkatkan keterampilan berpikir kritis dalam pembelajaran tematik siswa kelas IV SDN 03 terintegrasi Alai Kota Padang.

Penelitian lain yang mendukung penelitian ini dilakukan oleh Gunantara (2014) hasil penelitianya menunjukkan bahwa, model pembelajaran Problem Based Learning dapat meningkatkan kemampuan pemecahan masalah pada pembelajaran Matematika. Jadi untuk meningkatkan critical thinking dalam PPKn siswa, digunakan model pembelajaran Problem Based Learning (PBL) dengan integrasi pendidikan karakter. Selain meningkatkan critical thinking siswa, juga dapat menanamkan nilai-nilai karakter kepada siswa.

\section{Simpulan dan Saran}

Berdasarkan hasil dan pembahasan, maka dapat disimpulkan bahwa, terdapat pengaruh model pembelajaran problem based learning dengan intergrasi pendidikan karakter terhadap critical thinking PPKn siswa kelas IV di Gugus XV Kecamatan Buleleng Kabupaten Buleleng tahun pelajaran 2018/2019. Hal ini diperkuat dengan hasil rata-rata skor critical thinking kelompok eksperimen yang lebih tinggi dari pada kelompok kontrol. Jadi model pembelajaran problem based learning dengan intergrasi pendidikan karakter berpengaruh terhadap critical thinking PPKn siswa kelas IV di Gugus XV Kecamatan Buleleng Kabupaten Buleleng tahun pelajaran 2018/2019.

Berdasarkan simpulan di atas, dapat diberikan saran sebagai berikut. Kepada Siswa diharapkan dapat untuk memupuk karakter melalui pendidikan karakter yang diintegrasikan dalam pembelajaran agar menjadi generasi yang berkarakter, disamping meningkatkan critical thinking melalui model pembelajaran inovatif. Kepada Guru diharapkan dapat menerapkan model pembelajaran inovatif dalam pembelajaran untuk menarik minat belajar siswa sehingga dapat mencapai tujuan pembelajaran yang diharapkan. Kepada Peneliti lain yang ingin melakukan penelitian sejenis diharapkan dapat mengembangkan penelitian ini dengan menambahkan variabel penelitian ataupun menjadikan penelitian ini sebagai referensi.

\section{Daftar Pustaka}

Arends, R. I. (2008). Learning to Teach (terjemahan). Yogyakarta: Pustaka Pelajar. 
IVCEJ, Vol 2 No 2, Tahun 2019

Fauzi, F.Y., I. Arianto, E. Solihatin. 2013. "Peran Guru Pendidikan Pancasila dan Kewarganegaraan dalam Upaya Pembentukan Karakter Peserta Didik". Jurnal PPKN UNJ Online.Vol. $1, \quad$ No.2.Tersedia pada https://s3.amazonaws.com/academia.edu.documents/. Diakses pada 23 Januari 2019.

Fisher. 2009. Berpikir Kritis. Jakarta: Erlangga Jalal, Fasli. 2010a. Kebijakan Nasional Pendidikan Karakter : Tiga Stream Pendekatan. Jakarta: Kementerian Pendidikan Nasional.

Judiani, Sri. 2010. "Implementasi Pendidikan karakter di Sekolah Dasar Melalui Penguatan Kurikulum". Jurnal Pendidikan dan Kebudayaan. Vol.16, No.9, Edisi Khusus III. Tersedia pada http://jurnaldikbud.kemdikbud.go.id/index. php/jpnk/article/view/519/358. Diakses pada 23 Januari 2019.

Maolani, Rukaesih. 2015. Metodologi Penelitian Pendidikan. Depok : PT Rajagrafindo Persada.

Margono. 2014. Metodologi Penelitian Pendidikan. Jakarta : PT Rineka Cipta.

Murti, Bhisma. 2009. "Berpikir Kritis (Critical Thinking)". Seri Kuliah Budaya IImiah. Fakultas Kedokteran Universitas Sebelas Maret. Tersedia pada http://researchengenis.com. Diakses pada 25 Januari 2019.

Misbahuddin \& Iqbal Hasan. 2014. Analisis Data Penelitian dengan Statistik. Jakarta : PT Bumi Aksara.

Ngalimun. 2017. Strategi Pembelajaran. Yogyakarta: Dua Satria Offet

Saputra, A.T. 2015. "Peningkatan Kemampuan Berpikir Kritis Menggunakan Model Problem Based Learning (PBL) pada Pembelajaran Tematik Terpadu di Sekolah Dasar". EJournal Inovasi Pembelajaran SD. Vol.1. Tersedia pada https://docplayer.info/64172534Peningkatan-kemampuan-berpikir-kritis-menggunakan-model-problem-based-learningpbl-pada-pembelajaran-tematik-terpadu-di-sekolah-dasar.html. Diakses pada 25 April 2019.

Sumanto. 2014. Teori dan Aplikasi Metode Penelitian. Yogyakarta : CAPS (Center Of Academic Publishing Service).

Sudijono, Anas. 2015. Pengantar Evaluasi Pendidikan. Jakarta : PT RajaGrafindo Persada

Susongko, Purwo. 2010. "Perbandingan Keefektifan Bentuk Tes Uraian dan Teslet dengan Penerapan Grade Response Model (GRM)". Jurnal Penelitian dan Evaluasi Pendidikan. No.2. Tersedia pada http://repository.radenintan. ac.id/34/1/criticalthinking.pdf. Diakses pada 24 Januari 2019. 